\title{
Problems and Countermeasures of Small and Medium-Sized Enterprises Credit Guarantee Company
}

\author{
Wenshuai Chen \\ Jinan University, Guangzhou, China \\ Email: chan3293@sina.com
}

How to cite this paper: Chen, W.S. (2018) Problems and Countermeasures of Small and Medium-Sized Enterprises Credit Guarantee Company. Modern Economy, 9, 562-571.

https://doi.org/10.4236/me.2018.93036

Received: February 8, 2018

Accepted: March 25, 2018

Published: March 28, 2018

Copyright $\odot 2018$ by author and Scientific Research Publishing Inc. This work is licensed under the Creative Commons Attribution International License (CC BY 4.0).

http://creativecommons.org/licenses/by/4.0/

\section{(c) (i) Open Access}

\begin{abstract}
Small and medium-sized enterprises (SME) have increasingly played an important role in our development of economy. Financing has been restricting the development of SME. The credit guarantee company (CGC) for small and medium-sized enterprises has effectively relieved this problem, and also reduced the risk of commercial banks. It is conducive to the development of SME, CGC and commercial banks. But, in actually, there are many challenges preventing the function of CGC. This paper will analyze these problems from three aspects: the CGC itself, the cooperation with bank and the social environment. To solve the problem, we can strengthen risk management and improve the social environment.
\end{abstract}

\section{Keywords}

Small and Medium-Sized Enterprises (SME), Credit Guarantee Company (CGC)

\section{Definition of SME Credit Guarantee Corporation}

In 1999, the state economic and trade commission issued the guiding principles on establishing the pilot of credit guarantee system for small and medium-sized enterprises. The credit guarantee institution of small and medium-sized enterprises refers to the specialized agencies that have agreed with the creditors (including Banks and other financial institutions) to undertake the agreed obligations or to perform the debts when the debtor fails to perform the principal contract.

Due to insufficient credit, small and medium-sized enterprises are unable to obtain bank loans. The guarantee of the credit guarantee company can enhance 
the credit of small and medium-sized enterprises, so that enterprises can obtain more loans easily. At the same time, the credit guarantee company collects the premium as a reward for lending credit and managing risks. It not only solves the problem of financing of small and medium-sized enterprises, but also diversifies the risks of commercial Banks and increases their business. This is conducive to the sustainable development of SME, commercial Banks and credit guarantee companies.

According to the source of funds, the credit guarantee companies of small and medium-sized enterprises are divided into policy-based guarantee institutions, mutual guarantee institutions and commercial guarantee institutions. Policy-based guarantee institutions are set up by the central budget appropriations. They are not subject to profit and regulated by government agencies. The mutual guarantee institutions are funded by the member enterprise to help the member enterprise loan. The commercial guarantee institutions are established by investors to make profits [1].

\section{The Background of SME Credit Guarantee Corporation}

Small and medium-sized enterprises are playing an increasingly important role in promoting economic growth, enhancing market vitality and increasing employment. In 2015, the general office of the state council issued the guidelines on promoting mass innovation and entrepreneurship in the development of mass entrepreneurship space, in order to implement the innovation-driven development strategy. The policy supports innovation and entrepreneurship in all aspects from administrative examination and approval, intellectual property protection, financial support to improving financing channels and service platforms. In the future, more and more small and medium-sized enterprises will be born.

However, the financing problem has been restricting the rapid development of small and medium-sized enterprises. Small and medium-sized enterprises usually rely on internal accumulation or bank loans to obtain funds. Because of their small size, high risk and lack of credit, banks are often reluctant to lend to them. For one thing, Banks are lending most of their loans to state-owned enterprises. With abundant capital and high government credit, the default risk of state-owned enterprises is small. Secondly, small and medium-sized enterprises have large operation uncertainty, small assets, and lack of necessary collateral, which makes it less solvent. Finally, the management of small and medium-sized businesses is not standardized, which increases the difficulty of collecting information and investigating costs [2] [3].

Credit guarantee companies effectively alleviate the financing difficulties of SME. By providing third party guarantees, credit guarantee companies make it easier for SME to obtain bank loans and become an important force to promote the development of SME. SME credit guarantee companies also help commercial banks to transfer risks, increase customers and broaden their business, especially 
in the case of interest rate liberalization and increasingly fierce competition.

\section{Problems Existing in SME Credit Guarantee Companies}

\subsection{Small Scale and Poor Management}

The capital is small and lacks complement. Credit guarantee companies are faced with greater risks, and the greater the size of their own capital, the greater their ability to deal with risks. However, in actual operation, the capital of the credit guarantee company is small, and there is no effective follow-up source.

The guarantee company's capital comes from capital contribution and operating income. The minimum registered capital of a guarantee company is 5 million, mainly from shareholder capital or government appropriation. These contributions are usually one-off. Operating income mainly includes premium income and safe investment income. The guarantee rate shall not exceed $50 \%$ of the bank loan interest rate in the same period, and the investment amount shall be within $20 \%$ of the net assets and the investment direction shall be limited. The benefits are limited. Sometimes a loan loss can lead to the bankruptcy of the guarantee company.

The capital of the guarantee company is small. It is difficult to obtain the trust of the bank and the guarantee ability is low. The guarantee profit is limited. It is difficult to make up for the loss of compensation, and the capital gap is large.

The guarantee company takes all risks and lacks risk sharing. Against the background of interest rate liberalization, the competition between banks is increasingly fierce. The emergence of the credit guarantee company has transferred the risk of the bank, enhanced the security of the bank's assets, increased the customers for the bank, and improved the competitiveness of the bank. However, considering the security of their own funds, the banks generally require the guarantee company to assume joint and several guarantee liabilities and transfer all the risks to the guarantee company. Once the enterprise is unable to repay, the guarantee company will assume full responsibility for compensation. In Japan, there is a re-guarantee system by establishing a credit insurance public bank. The reinsurance company compensates the guarantee company.

Engage in unsecured business. According to the normal procedures, the guarantee business profit is low. Many credit guarantee companies are issuing usury, or using the online lending platform to provide both guarantee services and financing services. In accordance with the state regulations, the guarantee rate generally cannot exceed $50 \%$ of the bank loan interest rate of the same period. According to the benchmark interest rate for bank loans adjusted by the people's bank of China on October 24, 2015, the one-year period is $4.35 \%$, which means the guarantee rate is no more than $3 \%$. But in online lending platforms, lending rates are well above 3\%. For example, on the website of Credit Ease, if the loan is 100,000 yuan for one year, the average annual interest rate is $8.51 \%$ when the credit is good, otherwise the annual interest rate is $18.27 \%$. For the same loan, the credit guarantee company bears almost all of the risk, but the guaranteed income is far lower than the income from the direct loan. So many 
credit guarantee companies use registered capital or low interest bank loans to engage in private lending, or use online lending platforms to finance some enterprises especially in the credit crunch.

The internal management mechanism of the credit guarantee company is not perfect, and the professional quality is not high. Customers of SME credit guarantee companies generally do not meet the requirements of commercial bank loans. This means that credit guarantee companies have a higher risk than commercial Banks, so they must have a higher risk management capability. There needs to be a sound management mechanism to standardize the pre-loan review, the concern in the loan, and the supervision and management after the loan.

In reality, some guarantee companies are heavily involved in administrative intervention due to the investment of local government funds. They cannot choose the guaranteed object in accordance with the rules and have to provide guarantees for companies that do not meet the requirements. Some guarantee companies lack standard approval procedures, effective internal control system, smooth information communication and organization decision-making process. They lack the tracking management of the guarantee enterprises and the capital flow is chaotic. For example, the credit guarantee company requires the customer to pay the security deposit, as a kind of counter guaranty for the default. But many guarantee companies use these security deposits as their own funds to pay bank deposits or to make risky investments in usury.

The guarantee industry develops late in our country, and the attraction of talent is lower than that of traditional financial industries such as banking, insurance and securities. The guarantee industry lacks professional talents who are proficient in asset value assessment, risk analysis, economy, finance, technology and law. Meanwhile, the credit guarantee industry lacks professional qualification assessment system. Moreover, there is no clear punishment for the illegal operators, which makes the overall quality of employees in the credit guarantee industry lower [4].

\subsection{Credit Guarantee Companies Are in a Weak Position in Cooperation with Banks}

Banks do not trust credit guarantee companies and are unwilling to cooperate. There is information asymmetry between commercial banks and credit guarantee companies. Low registered capital, chaotic business and imperfect internal management system not only increase the risk of the credit guarantee industry itself, but also make it more difficult for commercial Banks to obtain information. There are often news reports that disclose credit guarantee companies operating illegally. The bankruptcy of credit guarantee companies is common because of the default of small and medium-sized enterprises. Therefore, commercial Banks lack trust in guarantee companies.

At the same time, commercial Banks tend to provide credit loans to large en- 
terprises, or secured loans with property collateral. Because of the high risk, the collection of information and management costs, the CBRC supervision, commercial banks are unwilling to provide loans to small and medium-sized enterprises. Credit guarantee companies actually transfer the repayment responsibility of SME to themselves. But commercial banks are reluctant to cooperate with credit guarantee companies, especially in the credit crunch, because of the lack of credit guarantee companies and the preference of traditional Banks.

Banks transfer almost all of their risk to credit guarantee companies. The loan is the basic business of the bank. The risk management ability is the basic ability of the bank and the bank realizes the profit by taking the risk. However, banks are reluctant to take the risk when lending to SME and transfer all of the risk to credit guarantee companies. The guarantee companies assume the high risk but enjoy the low income, which drives them to engage in other illegal and high-risk activities. As the bank is the provider of capital, once the credit guarantee company goes bankrupt, the risk is ultimately borne by the commercial bank.

Banks have moral hazard. Moral hazard refers to the actions of people engaged in economic activities to maximize their own utility while doing harm to others. That is to say, when the contracting party is not fully committed to the consequences of the risk, it will take the selfish behavior to maximize its own utility. Because credit guarantee companies bear all the risks, commercial banks do not consider risks when issuing loans, thus generating moral hazard. Banks will relax their pre-loan review of small and medium-sized enterprises and even lend to small and medium-sized enterprises that do not qualify. After granting loans, they relax vigilance and neglect management. In case of breach of contract, the guarantor shall compensate. This is even more serious when commercial Banks are working with government-type credit guarantee companies. It is well known that government credit is high, which addresses the bank's last concern - the risk of a credit guarantee company going bust. This will increase the risk of credit guarantee companies, reduce the use efficiency of financial capital, and weaken the function of the bank as a specialized management risk institution. For example, in April 2011, after a company's legal representative was involved in a criminal case, a bank still issued 5 million in loans and required a credit guarantee company to guarantee it. At last, the credit guarantee company made the payment.

\subsection{The Social Environment Is Not Good}

The legislation system of guarantee industry is not sound. Law is the most effective way to regulate individual behavior. There are several problems in the law and regulation of the guarantee industry in China. First, the starting point of the legislation is the department's regulations, and the effectiveness is lower. Guarantee industry risk is generally higher, and it involves the economic interests of banks, enterprises and individuals. Once a dispute arises, the effectiveness of departmental rules is difficult to solve, and the court's recognition is not high. Second, the operability is not strong. Some laws and regulations are not detailed. 
There is only one general rule, and there is no specific operational level. For example, there are no detailed rules on the post-loan recovery, the pre-loan review and other issues. Third, there is a lack of laws on guarantee institutions [5]. The guaranty act promulgated by China in 1995 is a guarantee for the whole society and does not stipulate the behavior of guarantee agency. The existing rules and guidelines on SME credit guarantee companies are mainly applicable to policy-typed credit guarantee companies. There is a lack of regulations for commercial and mutual credit guarantee companies, and the commercial credit guarantee companies in China's guarantee industry have a large proportion. With the support of small and medium-sized enterprises, the continuous opening of financial market, the continuous access of private capital and the increasing role of credit guarantee institutions, there will be more and more commercial and mutual credit guarantee agencies, and it is necessary to make special laws.

The lack of regulation. First, there is no clear regulator. Banks, securities and insurance all have their own special regulatory bodies. The guarantee industry does not have a dedicated government regulator. The government stipulates nine ministries and local authorities to determine the regulatory authorities, so the subject of supervision is not clear. All departments only supervise the matters related to themselves, which can easily produce many instructions and not conducive to execution. There will also be regulatory gaps for unrelated things.

Second, there is not enough regulation. There are a large number of credit guarantee companies lacking operating licenses in the society. Because of their lack of qualifications, they cannot cooperate with Banks or provide guarantees for small and medium-sized enterprises. They usually take deposits and make loans illegally. There are also a handful of guarantee companies with operating licenses illegally distributing usury. The existence of these phenomena indicates the lack of supervision in the credit guarantee industry.

Social credit deficiency. The phenomenon of credit loss is widespread in China. This is a weak link in the development of China's socialist market economy. Small and medium-sized enterprises are easy to be dishonest because of irregular operation and management, imperfect financial system, great difficulty in supervision and management, and weak resistance to risk. Sometimes, they falsify financial data and report higher income and assets in order to get a loan. Sometimes they change the loan use for high-risk projects or other projects without authorization. This increased the risk of credit guarantee companies, seriously restricted the development of the guarantee industry and violated the state's intention to support the development of small and medium-sized enterprises.

\section{Countermeasures}

\subsection{Credit Guarantee Companies Strengthen Their Own Management and Enhance Their Ability to Deal with Risks}

Increase capital supplement. First, absorb social capital and increase the finan- 
cial strength of guarantee companies. The main source of funds for policy-type guarantee companies is government financial allocation. After all, financial capital is limited. We should use financial capital as the leading force to attract private capital and exert the power of private capital. Commercial credit guarantee companies are more difficult to cooperate with Banks and should increase their capital strength to gain the trust of Banks. Second, establish government compensation mechanism [6]. For the guarantee company, the premium income is difficult to compensate for the loss of compensation. The existence of the guarantee company is to solve the problem of financing difficulty of small and medium-sized enterprises, which has great social benefits. Therefore, the government should strongly support it. The government can formulate special compensation mechanism to compensate for the loss of a certain proportion of projects that meet the national industrial policy. Third, expand business and increase profitability. The main business of the guarantee company is to guarantee the enterprise. Income consists of premium income and some security investment income, which is difficult to cover the risk. Guarantee companies should take advantage of it as intermediary agencies and actively expand the business diversification, such as credit rating, credit investigation, consulting company, assets appraisal business. This will not only increase revenue, but also strengthen the ability of the management guarantee business.

Build a risk-sharing mechanism. First, establish a re-guarantee mechanism [7]. The state establishes a policy-type re-insurance company to insure all the guarantee companies again. Second, improve the anti-guarantee system and innovate anti-guarantee content. Small and medium-sized enterprises have small scale and poor risk tolerance, so their guarantee company is very risky. In order to obtain loans, small and medium-sized enterprises can easily fabricate financial statements and transfer loans to high-risk projects. Therefore, the guarantee company should let the insured enterprise provide certain collateral to prevent the risk. But small and medium-sized enterprises often lack collateral. Therefore, it is necessary to innovate the content of anti-guarantee, and take accounts receivable or other items as collateral. Third, share risks with banks and work together. On the one hand, if the borrower defaults, the bank's losses can directly reduce the risk of the credit guarantee company. On the other hand, when the banks do not take risks, they will lend against the risk of the loan. When the Banks themselves take on some of the risk of lending, they will take full consideration of the risk of the loan, strengthen the cooperation with the guarantee company and reduce the risk of the whole loan. Finally, the banks have unique advantages. It has a strong information network, professional staff, advanced technical support, and can grasp the fund trend of the enterprise and track the use of funds. The credit guarantee company also understands the specific situation of small and medium-sized enterprises. So, the cooperation between banks and credit guarantee companies can effectively manage the security of loan funds and supervise the behavior of enterprises. 


\subsection{Building a Good External Institutional Environment}

We should raise the threshold for the guarantee industry. The guarantee industry frequently has problems, and is in a weak position in the cooperation with the bank, mainly because of its insufficient capital strength, management confusion and lack of credibility. First, raise the minimum registered capital. The guarantee industry is a high-risk industry. The greater the capital, the greater the risk tolerance. By raising the registered capital, we will eliminate some enterprises with insufficient funds, thus improving the strength of the whole industry. Second, increase censorship. When applying for the establishment of the guarantee company, the management department shall strictly examine its articles of association, feasibility report, qualification of employees, risk control and so on. This can improve the quality of the guarantee company from the source by improving the setting conditions.

Improve the social credit environment. Credit is the foundation of market economy and the guarantee of its healthy development. The essence of the credit guarantee company is to provide credit enhancement for small and medium-sized enterprises with their own credit, and more needs to have a good social credit environment to regulate the behavior of small and medium-sized enterprises. First, establish enterprise credit database. Make use of the information in the daily economic transactions between the bank and the enterprise to form a database on enterprise credit and make it public. Second, carry out enterprise credit rating. We will encourage the establishment of professional credit rating agencies, and make a comprehensive assessment of the business management and financial situation of enterprises in a scientific and reasonable way. The market mechanism is used to automatically regulate the credit behavior of small and medium-sized enterprises. Third, punish dishonesty. Through legislation and publicity, we encourage trustworthy behavior, punish dishonest behaviors, promote the values of honesty and trustworthiness in the society, and improve the credit awareness and level of small and medium-sized enterprises.

Improve the security related laws. First, make specific laws. The guarantee is a very broad concept, and it is only part of it to guarantee the financing of small and medium-sized enterprises. For policy-based guarantee and commercial guarantee, the source of capital contribution, operation purpose and operation mode are very different. Therefore, different laws should be established. Second, develop higher levels of law. At present, the guarantee industry mostly carries out the departmental rules. However, the effectiveness of departmental rules is limited, and disputes cannot be effectively resolved in the context of larger and more complex situations. Therefore, a higher level of law should be established to regulate credit guarantee behavior.

Strengthen supervision. First, clarify the subject of supervision. Each regulator has its own considerations, and there are bound to be conflicts and omissions. It is better to identify a major department and other departments to assist it. Second, strengthen information disclosure. Information disclosure can reduce 
information asymmetry and reduce transaction cost. Information disclosure can also effectively urge the guarantee company to improve corporate governance because of the supervision by investors, bank partners and even the public. Third, establish a guarantee association. The guarantee association can not only guide the guarantee companies from the professional and help the resource sharing among members, but also can strengthen the self-discipline of the industry. At the same time, it can also assist the government in formulating and implementing the industry development plan, and provide suggestions for the enactment of laws and regulations in the guarantee industry.

\section{Conclusion}

Aiming at the problems existing in the credit guarantee companies of small and medium-sized enterprises, this paper has made detailed analysis from three aspects of enterprise itself, bank relationship and social environment, and put forward specific Suggestions. The main conclusions are as follows. First, credit guarantee companies of small and medium-sized enterprises should strive to enhance their own financial strength, improve management level and enhance their ability to resist risks. Second, establish a risk-sharing mechanism. The government and enterprises set up re-guarantee and counter-guarantee system to spread the risk of the guarantee company. Third, the government should improve the supervision of the guarantee industry and build a good credit environment.

\section{Innovations and Limitations}

There are two innovations in this article. First, the article puts forward the counter-guarantee system when constructing the risk-sharing mechanism. The use of various forms of assets for collateral can increase financing channels and reduce the risk of guarantee companies. Second, this paper suggests that credit guarantee companies should expand related business. It can not only increase the source of income, but also reduce the information asymmetry between small and medium-sized enterprises.

This paper also has some limitations, which can be used as the direction of future research. First, we can delve into credit guarantee companies and bank cooperation models. Credit guarantee companies have been in a weak position in cooperation with Banks. By studying the cooperation model between them, we can get a deeper understanding about the distribution of risks and benefits between them. By improving the relationship between them, it is helpful to stimulate the enthusiasm of Banks and guarantee companies to serve the enterprise better. Secondly, we can discuss the establishment of the re-guarantee mechanism. The establishment of the re-guarantee mechanism can effectively spread the risk of credit guarantee companies. How to build the re-guarantee system, what role the government should play in it to improve the quality of the guarantee system is a question worth studying. 


\section{References}

[1] Shang, E.X. (2013) Research on Sustainable Development of SME Credit Guarantee Institutions. Dongbei University of Finance and Economics, Dalian.

[2] Lv, J.S. (2015) Thinking on Financing Difficulty and Financing of Small and Medium-Sized Enterprises. Financial Research, 11, 115-123.

[3] Xing, Y.C. and Liang, Y.X. (2013) Difficulties and Solutions for Small Enterprises in Financing. Journal of Jinan University (Social Science Edition), 23, 1-7, 91.

[4] Liu, D.J. (2008) Cooperative Risk Research of Commercial Banks and SME Credit Guarantee Companies. Wuhan University of Technology, Wuhan.

[5] Yang, X.J. (2013) The Improvement of the Legal System of Credit Guarantee for Small and Medium-Sized Enterprises in China. Technology and Law, No. 6, 43-53.

[6] Cao, F.Q. (2001) Establishing and Improving the Credit Guarantee System of Small and Medium-Sized Enterprises. Financial Research, 5, 41-48.

[7] Li, Y. and Xiang, D. (2008) Lack of Credit Guarantee for Credit Financing of Small and Medium-Sized Enterprises. Financial Research, 12, 179-192. 